\title{
A proposal for improving the KDIGO renal disease risk table
}

\author{
N. R. Robles · J. F. Macias · J. Alvarez-Gregori
}

Received: 10 April 2012/Accepted: 4 June 2012/Published online: 27 June 2012

(C) Springer Science+Business Media, B.V. 2012

Recent surveys have revealed that the prevalence of chronic kidney disease (CKD), particularly the hidden mild form (mildly elevated levels of serum creatinine or urinary albumin excretion), is surprisingly high in the general population. In recent years, the global epidemic of type-2 diabetes has led to an alarming increase in the number of patients with CKD. Most patients with CKD (over 50 million individuals worldwide) succumb to cardiovascular events, while each year over 1 million develop end-stage renal failure, which requires costly treatment and in many countries of the world, unaffordable renal replacement therapy by chronic dialysis or renal transplantation [1]

The diagnosis and management of CKD has been made easier in recent years by the Kidney Disease Outcomes Quality Initiative (K/DOQI) clinical practice guidelines of the US National Kidney Foundation. The K/DOQI guidelines advise that CKD can be defined and appropriately managed by a staging approach that relies on estimating the severity of kidney damage based on the degree of proteinuria and impaired kidney function, the latter assessed as a decrease in the glomerular filtration rate (GFR). CKD

N. R. Robles · J. F. Macias · J. Alvarez-Gregori Cardiovascular Risk Chair, University of Salamanca School of Medicine, Salamanca, Spain

N. R. Robles ( $\square)$

Unidad de Hipertensión Arterial, Hospital Infanta Cristina, Carretera de Portugal s/n, 06070 Badajoz, Spain

e-mail: nrrobles@yahoo.es is defined as kidney damage for $>3$ months, with or without decreased GFR, manifested by either pathologic abnormalities or markers of kidney damage such as proteinuria 3.4. If there are no signs of kidney damage, a diagnosis of CKD cannot be made until the GFR is $<60 \mathrm{~mL} / \mathrm{min} / 1.73 \mathrm{~m}^{2}$ [2]. Using this standard of measure, the National Kidney Foundation estimates that 20 million Americans have CKD, while an additional 20 million are at risk of the disease [3].

During this time, an increasing recognition has emerged about the definition and classification limitations, leading to a heated debate and calls for revisions, mainly in nephrology subspecialty journals. The leadership of KDIGO (Kidney Disease: Improving Global Outcomes), with the endorsement of K/DOQI, convened a Controversies Conference to provide a forum for an open discussion on this problem [4]. One important issue was whether or not the current classification (based on eGFR) should be modified to include additional factors associated with prognosis. The conference generated a table similar to the one used for the European Hypertension Guidelines [5]. It was drawn by a composite ranking of relative risks that enhances communication about prognosis in which colours indicate groups of patients at progressively higher risk for the major outcomes. This table (Fig. 1) would help clinicians, researchers and public health agencies to describe and prioritise efforts aimed at patients and populations at risk of renal disease.

The main improvement in the table is to add the value of urinary albumin excretion categorised by 


\begin{tabular}{|c|c|c|c|c|c|c|c|c|}
\hline \multirow{4}{*}{\multicolumn{4}{|c|}{$\begin{array}{l}\text { Composite ranking for } \\
\text { relative risks by GFR } \\
\text { and albuminuria } \\
\text { (KDIGO 2009) }\end{array}$}} & \multicolumn{5}{|c|}{$\begin{array}{c}\text { Albuminuria stages, } \\
\text { description and range }(\mathrm{mg} / \mathrm{g})\end{array}$} \\
\hline & & & & \multicolumn{2}{|c|}{$\mathrm{A} 1$} & \multirow{2}{*}{\begin{tabular}{|c|} 
A2 \\
High
\end{tabular}} & \multicolumn{2}{|c|}{ A3 } \\
\hline & & & & \multicolumn{2}{|c|}{$\begin{array}{l}\text { Optimal and } \\
\text { high-normal }\end{array}$} & & \multicolumn{2}{|c|}{$\begin{array}{l}\text { Very high and } \\
\text { nephrotic }\end{array}$} \\
\hline & & & & $<10$ & $10-29$ & $30-299$ & $300-$ & $\geqslant 2000$ \\
\hline \multirow{8}{*}{$\begin{array}{c}\text { GFR } \\
\text { stages, } \\
\text { descrip- } \\
\text { tion and } \\
\text { range } \\
(\mathrm{ml} / \mathrm{min} \\
\mathrm{per} \\
\left.1.73 \mathrm{~m}^{2}\right)\end{array}$} & \multirow{2}{*}{ G1 } & \multirow{2}{*}{$\begin{array}{l}\text { High and } \\
\text { optimal }\end{array}$} & $>105$ & REF & REF & LOW & MEDIUM & $\begin{array}{l}\text { VERY } \\
\text { HIGH }\end{array}$ \\
\hline & & & $90-104$ & REF & REF & LOW & MEDIUM & $\begin{array}{l}\text { VERY } \\
\text { HIGH }\end{array}$ \\
\hline & \multirow{2}{*}{ G2 } & \multirow{2}{*}{ Mild } & $75-89$ & REF & REF & LOW & MEDIUM & $\begin{array}{l}\text { VERY } \\
\text { HIGH }\end{array}$ \\
\hline & & & $60-74$ & REF & REF & LOW & MEDIUM & $\begin{array}{l}\text { VERY } \\
\text { HIGH } \\
\end{array}$ \\
\hline & G3a & $\begin{array}{c}\text { Mild- } \\
\text { moderate }\end{array}$ & $45-59$ & LOW & LOW & MEDIUM & HIGH & $\begin{array}{l}\text { VERY } \\
\text { HIGH }\end{array}$ \\
\hline & G3b & $\begin{array}{c}\text { Moderate- } \\
\text { severe }\end{array}$ & $30-44$ & MEDIUM & MEDIUM & HIGH & HIGH & $\begin{array}{l}\text { VERY } \\
\text { HIGH }\end{array}$ \\
\hline & G4 & Severe & $15-29$ & HIGH & $\mathrm{HIGH}$ & HIGH & HIGH & $\begin{array}{l}\text { VERY } \\
\text { HIGH }\end{array}$ \\
\hline & G5 & $\begin{array}{l}\text { Kidney } \\
\text { failure }\end{array}$ & $<15$ & $\begin{array}{l}\text { VERY } \\
\text { HIGH }\end{array}$ & $\begin{array}{l}\text { VERY } \\
\text { HIGH }\end{array}$ & \begin{tabular}{|l} 
VERY \\
HIGH
\end{tabular} & \begin{tabular}{|l} 
VERY \\
HIGH
\end{tabular} & $\begin{array}{l}\text { VERY } \\
\text { HIGH }\end{array}$ \\
\hline
\end{tabular}

Fig. 1 KDIGO 2009 Table of CKD risk progression

intensity to the estimation of GFR. Viberti et al. [6] coined the term microalbuminuria in 1982 to describe an increased urinary albumin excretion not detectable by the usual urinalysis but exceeding $20 \mu \mathrm{g} / \mathrm{min}$. With this criterion, they differentiated patients with insulindependent diabetes mellitus into those with and those without microalbuminuria and suggested that patients with microalbuminuria might have a worse renal prognosis. Microalbuminuria in patients with diabetes has been recognised not only as a predictor of progression of diabetic nephropathy but also as a powerful independent risk factor for cardiovascular disease [7-9]. Even in nondiabetic hypertensive patients microalbuminuria has been shown to predict renal and cardiovascular events, and a continuous relation between urinary albumin excretion and cardiovascular, as well as noncardiovascular, mortality has recently been found in a general population study [10-14].

A large body of evidence also shows that a greater initial level of proteinuria and an increase over time are independent predictors of both faster GFR decrease and development of kidney failure in patients with wide variety of types of kidney disease [15]. These results appear strong across all segments of the population and all levels of proteinuria, including levels of albuminuria less than the threshold for the definition of CKD. In many studies, proteinuria is associated more strongly with kidney disease outcomes than all other factors tested. Observational studies show a strong relationship between the presence of nephrotic-range proteinuria and increased risk of future GFR decrease irrespective of the cause and pathological state of kidney disease, with the exception of minimal change disease. The risk of progression to kidney failure during 5-10 years is 20-90\% in adults with primary kidney diseases. The same general pattern is observed for patients with nephrotic syndrome caused by systemic diseases. Conversely, complete remission of nephrotic syndrome (to normal urine total protein levels) is associated with a greater likelihood of stability of GFR and freedom from development of kidney failure [16].

Nevertheless, we think that current table is somewhat cumbersome to use and its use could be improved through an easy simplification. As it can be seen in Fig. 1, there are four entries for GFR with the same final risk when crossed with the albuminuria range, since prognosis does not change until GFR is below $60 \mathrm{ml} / \mathrm{min}$. This makes it difficult to use the table. The 
Table 1 Proposal for improving CKD risk table use

\begin{tabular}{lllll}
\hline $\begin{array}{l}\text { GFR } \\
(\mathrm{ml} / \mathrm{min})\end{array}$ & \multicolumn{4}{l}{ Microalbuminuria (mg/day or mg/g of creatinine) } \\
\cline { 2 - 5 } & $<30$ & $30-300$ & $300-1999$ & $>2000$ \\
\hline$>60$ & Reference & Low & Medium & Very high \\
$45-59$ & Low & Medium & High & Very high \\
$30-44$ & Medium & High & High & Very high \\
$15-29$ & High & High & High & Very high \\
$<15$ & Very high & Very high & Very high & Very high \\
\hline
\end{tabular}

table proposed is shown in Table 1. The table size is reduced but it remains useful for clinical and research uses while keeping unchanged the risk stages suggested by the KDIGO Table. There are no changes in classification but only a simplified view (stage I and II are unified), so that no information is missing and the risk calculation remains the same. Its advantage is that prognoses are easier and faster to get.

The Conference report stated that the ultimate goal of improving global outcomes depends on successful implementation of the updated guidelines worldwide. The value of our proposal for the definition and classification of chronic kidney disease stems from its ability to reduce efforts by simplifying the table used. Thus, we expect that it can be used more widely in clinics.

Acknowledgments Authors thank Professor Jesus Baigorri for correcting English grammar.

\section{References}

1. Dirks JH, de Zeeuw D, Agarwal SK, Atkins RC, CorreaRotter R, D'Amico G (2005) Prevention of chronic kidney and vascular disease: toward global health equity-the Bellagio 2004 declaration. Kidney Int 99(Suppl):S1-S6

2. National Kidney Foundation (2002) K/DOQI clinical practice guidelines for chronic kidney disease: evaluation, classification, and stratification. Kidney disease outcome quality initiative. Am J Kidney Dis 39(suppl 1):S1-S246

3. National Kidney Foundation. Chronic Kidney Disease (CKD). Available at http://www.kidney.org/kidneydisease/ ckd/index.cfm. Accessed 26 October 2005

4. Levey AS, de Jong PE, Coresh J et al (2009) The definition, classification and prognosis of chronic kidney disease: a
KDIGO Controversies Conference report. Am J Kidney Dis 54:205-226

5. Mancia G, De Backer G, Dominiczak A et al (2007) ESHESC practice guidelines for the management of arterial hypertension: ESH-ESC task force on the management of arterial hypertension. J Hypertens 25:1751-1762

6. Viberti GC, Hill RD, Jarret RD, Argyropoulos A, Mahmud U, Keen H (1982) Microalbuminuria as a predictor of clinical nephropathy in insulin-dependent diabetes mellitus. Lancet i:1430-1432

7. Dinneen SF, Gerstein HC (1997) The association of microalbuminuria and mortality in non-insulin-dependent diabetes mellitus: a systematic overview of the literature. Arch Intern Med 157:1413-1418

8. Adler AI, Stevens RJ, Manley SE, Bilous RW, Cull CA, Holman RR (2003) UKPDS group: development and progression of nephropathy in type 2 diabetes: The United Kingdom Prospective Diabetes Study (UKPDS 64). Kidney Int 63:225-232

9. Mogensen CE (2003) Microalbuminuria and hypertension with focus on type 1 and type 2 diabetes. J Intern Med 254:45-66

10. Gerstein HC, Mann JF, Yi Q, Zinman B, Dinneen SF, Hoogwerf B et al (2001) Albuminuria and risk of cardiovascular events, death, and heart failure in diabetic and nondiabetic individuals. JAMA 286:421-426

11. Jensen JS, Feldt-Rasmussen B, Strandgaard S, Schroll M, Borch- Johnsen K (2000) Arterial hypertension, microalbuminuria, and risk of ischemic heart disease. Hypertension 35:898-903

12. Bigazzi R, Bianchi S, Baldari D, Campese VM (1998) Microalbuminuria predicts cardiovascular events and renal insufficiency in patients with essential hypertension. J Hypertens 16:1325-1333

13. Hillege HL, Fidler V, Diercks GFH, van Gilst WH, de Zeeuw D, van Veldhuisen DJ et al (2002) For the prevention of renal and vascular end stage disease (PREVEND) study group. Urinary albumin excretion predicts cardiovascular and non-cardiovascular mortality in general population. Circulation 106:1777-1782

14. Robles NR, Mena C, Velasco J, Angulo E, Garrote T, Garcia Gallego F (2008) En representación de los investigadores del estudio MICREX Riesgo cardiovascular asociado a microalbuminuria en pacientes diabéticos y en pacientes con hipertensión arterial. Med Clin (Barc) 130:206-209

15. National Kidney Foundation (2002) K/DOQI clinical practice guidelines for chronic kidney disease: evaluation, classification, and stratification. Am J Kidney Dis 39(suppl 1):S1-S266

16. Levey AS, Cattran D, Friedman A, Miller WG, Sedor J, Tuttle K, Kasiske B, Hostetter T (2009) Proteinuria as a surrogate outcome in CKD: report of a scientific workshop sponsored by the national kidney foundation and the US food and drug administration. Am J Kidney Dis 54: 205-226 